\title{
Eduard Niznansky. Holokaust na Slovensku 7. Vztah slovenskej majority a zidovskej minority. (nacrt problemu). Bratislava: Nadacia Milana Simecku, 2005.
}

Nina Paulovicova, University of Alberta

176 The recently published "The Holocaust in Slovakia 7. The relationship between the Slovak Majority and the Jewish Minority" is the seventh volume of a thematically organized edition of selected archival documents relating to the Holocaust in Slovakia. This ambitious project of the "Milan Simecka Foundation" and the Jewish religious community in Bratislava, Slovakia, was initiated in 2001. Given the vicissitudes of political turmoil following the 1989 transition of post-Communist Slovakia to capitalism, the palpable escalation of nationalism, and the effort to appropriate history to the needs of crystallizing political formations, the methodology of "The Holocaust in Slovakia" document series has successfully withstood the influence of these pressures and avoided both a black and white categorization and a simplified hero-villain stigmatization.

The seventh volume of the documents series lends weight to the theories that emphasize the negative impact of 'Aryanization', or the transferal of Jewish businesses to Slovak hands. Financial losses of the banks, tax losses of the state, supply problems, and the failure of inexperienced 'Aryanizers' to cope with the finances and management of the Jewish firms are just a few examples. The negative impact of the Aryanization is palpable even in postwar society. Some documents indicate new avenues of further research in postwar financial institutions and restitution funds such as the restitution cases of the Department of Industry and Commerce fund. Research of this scale would certainly shed more light on the 
personal and financial aspects of the Aryanization and the multiple facets of the interaction between Aryanizers and surviving Jews in a context of increasing communist control. Interestingly, Niznansky also hints at an alternative angle, the possible re-conceptualization of Aryanization within the context of nationalization in the 1940s and 1950s. The process of nationalization was carried out under the auspices of both totalitarian regimes: the clerico-fascist state, which initiated the nationalization of Jewish property, and communism, which embraced nationalization in full and targeted almost all forms of private property. What the author seems to imply is that nationalization of enterprises during communism was just a continuation of Aryanization wrapped up in a radically different ideological coat. Since the editor does not elaborate on this idea, the reader is left to guess the editor's view about Aryanization within the context of totalitarianism. Whereas Aryanization represented a caesura in the community along national lines, postwar nationalization under the auspices of communism made its "cut" more along class lines.

In order to elucidate the nature of the Holocaust in Slovakia the volume targets the interaction between the Jewish minority and the Slovak majority. The editor emphasizes the importance of examining the social stratification of the Slovak population after the exclusion of Jews from the social, political and economic life of the Slovak State. In particular, Niznansky is concerned with the "new social strata" that replaced the Jews and benefited from their socioeconomic exclusion. It is quite obvious that the Slovak government had striven to integrate the larger social spectrum into the political process and Aryanization was a viable tool for such opinionmanipulation. The editor believes that an examination of the majority's reaction to the "social engineering" (the term coined by 
Niznansky to refer to the Aryanization of Jewish property and the deportation of the Jews) of Hlinka Slovak People's Party, would enable a better understanding of the origins and the nature of the Holocaust in the Slovak milieu. What is precisely Niznansky's theory about the nature of the Holocaust in Slovak milieu? The pauperization of the Jews in Slovakia had transformed the "Jewish question" into a serious social problem by the fall of 1941. Niznansky postulates that the "Final Solution" represents a domestic pragmatic response to the inability of the administration to handle the severe pauperization of the Jews -- a theory partly touched on by Rotkirchen, Kamenec and Fatran.

Anti-Semitism was a crucial determinant of the reactions and attitudes of the majority of the population to the internal developments of the state. Niznansky argues that pre-war, non-racist anti-Semitism had acquired several dimensions: religious (Jews as "Christ-killers."), economic or social ("Jews as exploiters of Slovaks; Jewish owners of inns as responsible for the alcoholism of Slovaks.") and political ("Jews as adherents of liberal or leftist political views."). (9) The tensions between autochthonous antiSemitism and imported Nazi forms readable through the moderateradical confrontation, eventually resulted in deportation as the most radical expression of the anti-Semitic policy of the Slovak State. Niznansky concludes that both the participation of Slovaks in the process of the pauperization of Jewry and the escalation of antiSemitism through propaganda and diffused terror were responsible for the overall passivity of the majority of Slovaks and their lack of interest in rescuing Jews. (27) Yet, it is precisely here, in the reviewed volume of the selected documents, that reader gets an impression of a more nuanced texture of wartime behavioral patterns of the Slovak population rather than a simplistic rejection of the 
population's passivity. The format of Raul Hilberg's 'victimbystander-perpetrator' approach does not hold up in the face of these documents. Often the documents attest to the failure of any attempt to pigeonhole the conduct of contemporaries into neat categories. The reaction of 104 workers, primarily railway workers, who signed a petition to keep a reliable and conscientious professional Jewish watchmaker Vojtech Stromf in his business, is hardly an example of a "passive" mass. This group of railway workers refused to comply with the decision of the authorities because they did not want to walk long distances to other villages and ask some "stranger" watchmaker to fix their watches. This case attests not only to an effort to protect one's own interests from the government's encroachments, but possibly also an attempt to rescue a Jew from deportation. The case of A. Morvai, a war invalid from Hronsky Benadik who was given permission to Aryanize a radio, reveals hidden nuances of a "perpetrator" category. The editor, perhaps somewhat hastily describes Morvai's Aryanization of the radio as a "voluntary participation in stealing of [Jewish] property." Only after 41.3 percent of radios were distributed to organizations of the Hlinka Guards, 20.6 percent to schools, and 10 percent to orphanages and workers' shelters were the rest of the radios Aryanized by noninstitutional and civil members of society. One must at least recognize the odd texture of the "perpetrator" category in this war invalid's conduct. Niznansky claims that individuals who sought to be allowed to 'Aryanize' Jewish property consciously exercised their free will. Such individual "must (should, might) have had realized that he had come closer to the [totalitarian] regime."(16) I find this to be an example of a historian who retrospectively assesses events from their advantageous position in already knowing how the tragic events will unfold. The fact that an individual decided to take part in 
Aryanization might have as well demonstrated that some Slovaks simply failed to see the pernicious impact of the Aryanization process at all. Some might have accepted the generally given view spread by anti-Semitic propaganda that "they are carrying out social justice" (for example the distribution of radios to the socially marginal) rather than that they were siding with an "evil regime." Yet these categorical claims in the introduction are immediately subjected to the editor's own questioning: he at once acknowledges a "political (perhaps unwanted)- [!]" dimension of the decision to take part in the process of Aryanization. Clearly, the victim-perpetratorbystander model hardly acknowledges the presence of the chiaroscuros of the human psyche, personal biases, dilemmas or extreme behavioral reversals. Also, one must keep in mind the changing nuances of Slovak-German relations that molded the behavioral patterns of the Slovak majority in accordance with the given political contexts of the $1938-1945$ period.

This volume offers a valuable insight into one facet of SlovakJewish relations; one traced through the prism of anti-Semitism and anti-Semitic legislation namely, Aryanization. The seven volumes of "The Holocaust in Slovakia" edition, of which this volume is its latest, have to be consulted in reference to one another. Since the thematic approach might have resulted in the repetition of the same document in other volumes, the editor avoided the unwanted duplication by listing a handy reference to relevant documents. The reader is presented with the content of the district offices' agendas and notary and police station records in their original forms with minor corrections of evident misprints and misspellings of proper names. In case some of the documents were not preserved in the archives, the author opted to take advantage of documents in the contemporary press.(104) Given the extensive research carried out in 
the Slovak National Archives, the Military History Archives in Trnava, the Archives of the Ministry of the Interior of the Czech Republic, the Yad Vashem Archives in Jerusalem, local archives in Bratislava, Nitra and eight regional archives, this edition certainly represents a valuable contribution to scholarship on the Holocaust within the Central European milieu. 